\title{
Neurological Status Disturbances Caused by Mercury Exposures from Artisanal Gold Mining Area in West Aceh, Aceh Province
}

\author{
Sofia ${ }^{1}$, Tilaili Ibrahim ${ }^{2}$, Mirza Risqa $^{3}$ \\ ${ }^{I}$ Environmental Health Department, Faculty of Medicine, Syiah Kuala University, Indonesia \\ sofia_acheh@yahoo.com \\ ${ }^{2}$ Public Health Department, Faculty of Medicine, Syiah Kuala University, Indonesia \\ tilailiibr_dr@yahoo.com \\ ${ }^{3}$ Faculty of Medicine, Syiah Kuala University, Indonesia \\ mrisqa17egmail.com
}

\begin{abstract}
Artisanal gold mining activities in developing countries are still in concern with environmental and health issues regarding the impact which results from the activities. Amalgamation technique using mercury was commonly applied in extracting gold from the ore. During the process, mercury releases into the environment in its metallic form and mercury vapor. Mercury releases to environment can harm population who work or live near mining area. Mercury is a highly toxic metal and it can penetrate nervous systems as the main target organ. Acute and chronic neurological disturbances can also be experienced by the communities. The aim of this study was to determine the relationship between occupation in the mining process, length of time of mercury exposure and neurological status disturbances in communities near artisanal gold mining area in West Aceh, and is known now as Aceh Jaya district, Aceh Province, Indonesia. A cross sectional design was conducted with 78 respondents who lived in villages namely, Paya Seumantok, Panggong, and Curek. Samples were collected by random sampling and respondents were interviewed and given general physical examination. Data were analyzed by Chi-Square test at $\alpha=0.05$. The results of this study showed that occupation in mining process has relationship with neurological status disturbances $(p=0.004)$ whereas length of time of mercury exposure showed no relationship to neurological status disturbances $(p=0.650)$. Respondents have experienced neurological disturbances such as headache $(\mathbf{4 8 . 7 \%})$, insomnia $(37.2 \%)$, tremor $(10.3 \%)$, memory loss and mood changes $(9.0 \%)$, hearing impairment and somatosensory disturbances $(3.8 \%)$. It can be concluded that efforts for monitoring and evaluation on artisanal gold mining in the areas have to be made by local government and stakeholders to prevent widespread of epidemy on mercury disasters. It is also needed to follow up the neurological status disturbances of the respondents clinically through intensive examination.
\end{abstract}

Keywords - neurological status, mercury exposure, artisanal gold mining, acute neurological disturbances, chronic neurological disturbances

\section{INTRODUCTION}

Artisanal gold mining is still widely practiced in developing countries and low income countries.
Indonesia as one of the developing countries which has abundance of minerals, such as gold, tin, coal, silver, has to control process of earth's crust exploration. Aceh as one of the provinces in Indonesia reported actively in mining activities, for example in West Aceh. The activities run traditionally using trommel and used mercury in amalgamation process. Workers use this toxic chemical in the workplace and also keep them at home.

United States Government Agency for Toxic Substances and Disease Registry ranked mercury in the third position as the most toxic elements or substances that continuously dumped into waterways and soil, spilled into the atmosphere, and contaminated the food and water [1]. Methyl mercury has a relatively long biological half-life in humans. Its half-life is estimated as an average of 70 days and can accumulates in the human brain causing irreversible damage due to long retention time in the body[2].

Prolonged exposure to mercury cause acute and chronic toxicity. Acute toxicity including changes in mood, headaches, hearing impairment, impaired speech (dysarthria) while chronic toxicity detected as tremor, ataxia cerebral, decline hearing and vision, tingling of the mouth to the hand, impaired memory, impaired sensation and insomnia [3]. Cases had been reported related to mercury toxicity, such as Minamata Disease in Japan in 1932 and 1968 which resulted in an epidemic that affected 50,000 poisoned and more than 2,000 people 
permanently disabled. In 1950, appear cases with severe symptoms include sensory loss, ataxia, blindness, impaired smell and hearing and disequilibrium syndrome. More serious symptoms causing convulsions, paralysis and even death[4].

Several research related to the impact of the use of mercury in artisanal gold mining had been done around the world ([5],[6],[7],[8],[9]). In Indonesia, research on artisanal gold mining had been conducted ([10], [11], [12], [13], [14]) but it is still limited on research topic related to the impact of mercury on neurological disturbances. Due to that reason, this study aims to determine the relationship of occupation and length of time of mercury exposure to neurological status disturbances in the workers and communities in artisanal gold mining area in West Aceh, Aceh Province, Indonesia.

\section{Materials And Methods}

\section{A. Study Area}

This study was conducted in Krueng Sabee sub districts, West Aceh district, Aceh Province, Indonesia from October 2013 until January 2014. Historically, in 2002 this district was separated into three district, namely West Aceh, Nagan Raya, and Aceh Jaya districts. Krueng Sabee is one of the sub districts which is affiliated under Aceh Jaya district.

\section{B. Study Design}

The study used analytical observational design with cross sectional approach.

\section{Sampling}

The population in this study is all villagers. The total is 400 people, which are spread across three villages, namely Paya Seumantok, Panggong, and Curek. The selected sample for this study were those who were willing to engage in the research and fulfilled the inclusion criterias. A total of 78 respondents were chosen through random sampling. Sample size were calculated using Lemeshow's formula. Inclusion criteria that were identified were communities who have occupations as gold miners and non gold miners who lived near mining processing areas, aged 15-65 years. Exclusion criteria include people who were dumb; using teeth amalgam contained mercury; and using whitening cosmetics contained mercury.
Respondents were interviewed and physically examined their health status. Body mass index were also calculated.

\section{Questionnaires}

A structured questionnaires used in this study were modified from [4] and [18]. Before administered to respondents, questionnaires were tested for validity and reliability. Validity for each question listed in the questionnaires was calculated by item correction correlation with value of $r>0.444$ while reliability was calculated using Cronbach's Alpha Test with value of $r>0,755$. All respondents were given informed consent before interviewing. Information addressed in the questionnaires are personal identity, occupation, length of time of mercury exposures, acute and chronic neurological disturbances. List of acute and chronic neurological disturbances were extracted from [4] and [15].

\section{E. Neurological Disturbances}

Neurological disturbances were grouped into acute neurological disturbances and chronic neurological disturbances. Acute neurological disturbances consists of headache, hearing impairment, loss of sense of smell, somatosensory disturbances, dysarthria, and occassionally emotional lability. Chronic neurological disturbances were consists of tremor, ataxia cerebral, numbness from lips to hand and fingers, memory loss, somatosensory disturbances, visual impairment, and insomnia.

\section{F. E. Data Analysis}

The relationship between occupation and neurological status disturbances, as well as relationship between length of time of mercury exposure and neurological status disturbances was calculated with Chi-Square test. Significancy was set at $\alpha=0.05$.

\section{RESULTS AND DISCUSSION}

\section{A. Characteristics of Respondents}

Characteristics of respondents were categorized into age, gender, and occupation. Tabel 1 shows that the majority of respondents have category of age 26-35 years old $(28,35.90 \%)$. For gender category, respondents were mostly men (49, $62.82 \%$ ). Occupation category of the respondents 
shows that a total of $42(53.85 \%)$ respondents work as gold miners.

TABLE I

RESPONDENTS CHARACTERISTICS

\begin{tabular}{|l|c|c|}
\hline Characteristics & $\begin{array}{c}\text { Frequency } \\
\text { (n) }\end{array}$ & $\begin{array}{c}\text { Percentage } \\
(\mathbf{\%})\end{array}$ \\
\hline Age (Years) & & \\
\hline $15-25$ & 14 & 17.95 \\
\hline $26-35$ & 28 & 35.90 \\
\hline $36-45$ & 22 & 28.20 \\
\hline $46-55$ & 11 & 14.10 \\
\hline $56-65$ & 3 & 3.85 \\
\hline Gender & & \\
\hline Man & 49 & 62.82 \\
\hline Woman & 29 & 37.18 \\
\hline Occupation & & \\
\hline Gold Miners & 42 & 53.85 \\
\hline Farmers & 18 & 23.07 \\
\hline Private employees & 10 & 12.82 \\
\hline Civil servants & 3 & 3.85 \\
\hline Student & 2 & 2.56 \\
\hline Trader & 3 & 3.85 \\
\hline
\end{tabular}

\section{B. Acute Neurological Disturbances}

Acute neurological dist urbances detected in the respondents in Krueng Sabee sub district, West Aceh district, Aceh Province, Indonesia are presented in the following Table 2 .

TABLE II

RESPONDENTS’ ACUTE NEUROLOGICAL DISTURBANCES

\begin{tabular}{|l|c|c|}
\hline \multicolumn{1}{|c|}{$\begin{array}{c}\text { Acute Neurological } \\
\text { Disturbances }\end{array}$} & $\begin{array}{c}\text { Yes } \\
\mathbf{n}(\boldsymbol{\%})\end{array}$ & $\begin{array}{c}\text { No } \\
\mathbf{n}(\boldsymbol{\%})\end{array}$ \\
\hline Headache & $38(48.7)$ & $40(51.3)$ \\
\hline Hearing impairment & $3(3.8)$ & $75(96.2)$ \\
\hline Loss of sense of smell & $0(0)$ & $78(100)$ \\
\hline Somatosensory disturbances & $0(0)$ & $78(100)$ \\
\hline Dysarthria & $0(0)$ & $78(100)$ \\
\hline Occassionally emotional lability & $7(9.0)$ & $71(91.0)$ \\
\hline
\end{tabular}

Based on the results in Table 2, the highest acute neurological disturbances was headache 38(48.7\%). The second highest was ocassionally emotional lability $7(9.0 \%)$ followed by hearing impairment $3(3.8 \%)$. Similar acute neurological disturbances such as phsychiatric symptomatology, visual impairment, hearing impairment, and olfactory and gustatory disturbances also resported as in [4]. Hearing impairment occured due to disturbances in temporal transverse gyrus area in nervous system. Methyl mercury can pass blood brain barrier and it hamper cytoplasmatic and inhibits astoglia cell.
Furthermore these can stimulate vesicular glutamate to produce glutamate quickly into extracellular and accumulated. This pathways cause calcium ions $\left(\mathrm{Ca}^{2+}\right)$ penetrate the cell through N-methyl-Daspartate (NMDA) channel receptor which resulted in mitochondria transport dysfunction and lead to nerve damage at the end. Animal study had been conducted to mice which demonstrates that the poisoning by methylmercury changes the nitrergic activities of adult mice and increase the release of neurotransmitters such as acetylcholine, dopamine, norepinephrine, and serotonin [16].

\section{Chronic Neurological Disturbances}

Chronic neurological disturbances detected in respondents in Krueng Sabee sub district, West Aceh district, Aceh Province, Indonesia are presented in the following Table 3.

TABLE III

RESPONDENTS' CHRONIC NEUROLOGICAL DISTURBANCES

\begin{tabular}{|l|c|c|}
\hline \multicolumn{1}{|c|}{ Chronic Neurological Disturbances } & $\begin{array}{c}\text { Yes } \\
\mathbf{n}(\boldsymbol{\%})\end{array}$ & $\begin{array}{c}\text { No } \\
\mathbf{n}(\boldsymbol{\%})\end{array}$ \\
\hline Tremor & $8(10.3)$ & $70(89.7)$ \\
\hline Ataxia cerebral & $0(0)$ & $78(100)$ \\
\hline Numbness from lips to hand and fingers & $0(0)$ & $78(100)$ \\
\hline Memory loss & $7(9.0)$ & $71(91.0)$ \\
\hline Somatosensory disturbances & $3(3.8)$ & $75(96.2)$ \\
\hline Visual impairment & $0(0)$ & $78(100)$ \\
\hline Insomnia & $29(37.2)$ & $49(62.8)$ \\
\hline
\end{tabular}

The results in Table 3 showed that insomnia was the highest chronic neurological disturbances $29(37.2 \%)$ followed by tremor $8(10.3 \%)$, memory loss 7(9.0\%), and somatosensory disturbances $3(3.8 \%)$. Mercury has ability to pass blood brain barrier and this may affect irreversible brain damage. Somatosensory disturbances occured to human who exposed to mercury due to disturbances of sensory nerve. Damage of girus precentral manifest to tremor [16]. Memory disturbances can occur due to decrease of glutamate uptake in the body [16].

Mercury compounds can contribute to toxic health effects by different mechanisms, such as changing intracellular calcium balance and membrane potential, altering cell membrane integrity, disturbing or inhibition of enzymes, inducing oxidative stress, inhibition of protein and DNA synthesis and disturbing immune functions. Methylmercury is primarily responsible for the 
neurological alteration from mechanisms which related to the toxic increase in reactive oxygen species (ROS) [18].

\section{Occupation and length of time of Mercury Exposure to} Neurological Status Disturbances

Statistical analysis of relationship between occupation and neurological status disturbances as well as relationship between length of time of mercury exposure and neurological status disturbances are presented in Table 4.

TABLE IV

THE RELATIONSHIP BETWEEN OCCUPATON AND LONG TIME OF MERCURY EXPOSURE TO NEUROLOGICAL STATUS DISTURBANCES

\begin{tabular}{|c|l|l|l|l|}
\hline \multirow{2}{*}{ Variable } & \multicolumn{3}{|c|}{$\begin{array}{c}\text { Neurological Status } \\
\text { Disturbance }\end{array}$} & \multirow{2}{*}{ p-value } \\
\cline { 2 - 4 } & $\begin{array}{c}\text { Normal } \\
\mathbf{n}(\%)\end{array}$ & $\begin{array}{c}\text { Acute } \\
\mathbf{n}(\boldsymbol{\%})\end{array}$ & $\begin{array}{c}\text { Chronic } \\
\mathbf{n}(\boldsymbol{\%})\end{array}$ & \\
\hline Occupation & & & & \\
\hline Smelter & $7(16.7)$ & $8(19.0)$ & $27(64.3)$ & \multirow{2}{*}{0.004} \\
\hline Non-smelter & $18(50.0)$ & $7(19.4)$ & $11(30.6)$ & \\
\hline $\begin{array}{l}\text { Length of time of } \\
\text { Mercury Exposure }\end{array}$ & & & & \\
\hline$\geq 5$ years & $11(29.7)$ & $6(16.2)$ & $20(54.1)$ & \multirow{2}{*}{0.650} \\
\hline$<5$ years & $14(34.1)$ & $9(22.0)$ & $18(43.9)$ & \\
\hline
\end{tabular}

The results in Table 4 showed that relationship between occupation and neurological status disturbances among respondents in artisanal gold mining in three villages in Krueng Sabee sub district, West Aceh district, Aceh Province, Indonesia is significantly different $(\mathrm{p}<0.05)$. Smelters have more chronic neurological disturbances than non-smelter. For acute neurological disturbances, smelters and non-smelters nearly the same (19.0\% vs. $19.4 \%)$. However, non-smelters have higher normal status of neurological disturbances compared to smelters. This findings similar to [11]. Smelters have higher risk to mercury toxicity than non-smelter due to frequently used of mercury at workplace during amalgamation process in extracting the gold in artisanal gold mining activities compared to nonsmelters who have lower chance in direct contact with mercury regarding their occupational status which was not involved mercury. Lestarisa also stated that the higher frequency of contact with mercury by smelters the higher doses of mercury may enter into the body. Routes of mercury administration into human body are known via inhalation, dermal, and oral routes[11]. A study had been done to workers exposed to mercury in residents of Guizhou (China), who are known to suffer mercury contamination with concentrations levels of $7-10 \mathrm{ng} / \mathrm{mL}$ [19]. In addition, mercury potent to bioaccumulate in human body in liver, kidney, and nervous systems [20].

Length of time of mercury exposure showed to have no relationship with neurological status disturbances $(p>0.05)$. Rianto has similar results to this study [20]. Many factors may influences to mercury toxicity in human body, such as immunity, nutritional status, and use of personal protective equipment. Mercury can affect disfunction of autoimmune in human population. Nutritional status also play a role in mercury accumulation in the body [21]. Miners which have body mass index higher or lower positively have higher mercury in their urine whereas miners with normal body mass index found little mercury in their urine [22]. Other factors that may affect accumulation of mercury in the body systems are contaminated air, water, and food near the mining areas. Human population and living things around areas of the artisanal gold mining can received impact from the waste of the activities. The wastes reach the air, water, and soil near the vicinity and then population can get contaminated air contained mercury, household may use contaminated water source contained mercury, and food source that come from their farmyard and river also contained mercury. It should be of concern that to live near artisanal gold mining areas which used mercury in the amalgamation process may increase to mercury toxicity.

For workers, gold miners and smelters, the use of personal protective equipments have to put in priority in order to protect the body from occupational exposures of mercury toxicity [14]. United Nations Environment Program (UNEP) and World Health Organization (WHO) recommend to use personal protective equipments to decrease possibility of health impacts to workers [15].

\section{CONCLUSIONS}

Neurological status disturbances were not only influence gold miners and smelters but also to communities who lived near the gold mining areas. For that fact, it is needed to build awareness on impacts of mercury toxicity to human health among 
workers and communities. Programs on monitoring, evaluation and controlling of gold mining activities have to be implemented by local government to minimize mercury neurological disturbances to communities near the area.

\section{ACKNOWLEDGMENT}

This work was supported by Health Professional Education Quality (HPEQ) Project, Faculty of Medicine, Syiah Kuala University. We thank the respondents and residents of Krueng Sabee subdistrict for their cooperation.

\section{REFERENCES}

[1] Rice, K.M., Walker, E.M., Wu, M., Gillette, C. and Blough, E.R.(2014). Environmental mercury and its toxic effects. Journal of Preventive Medicine \& Public Health, 47, 74-83.

[2] Ninomiya,T., Imamura,K., Kuwahata,M., Kindaichi,M., Susa, M andEkino,S. (2005). Reappraisal of somatosensoty disorders in methylmercury poisoning. Neurotoxicology and Teratology, 27,643653.

[3] Li, P., Feng, X.B., Qiu, G.L., Shang, L.H. and Li, Z.G. (2009). Mercury pollution in Asia: A review of the contaminated sites. Journal of Hazardous Materials. 168, 591-601.

[4] Ekino, S., Susa, M., Ninomiya, T., Imamura, K. and Kitamura, T. (2007). Minamata disease revisited: An update on the acute and chronic manifestations of methyl mercury poisoning. Jounal of Neurological Sciences. 262,131-144.

[5] Baeuml, J., Bose-O'Reilly, S., Gothe, R.M., Lettmeier, B., Roider, G., Drasch, G. and Siebert, U. (2011). Human biomonitoring data from mercury exposed miners in six artisanal small-scale gold mining areas in Asia and Africa. Minerals.1,122-143.

[6] Shandro, J.A., Veiga, M.M. and Chouinard, R. (2009). Reducing mercury pollution from artisanal gold mining in Munhena, Mozambique. Journal of Cleaner Production. 17,525-532.

[7] Charles, E., Thomas, D.S.K., Dewey, D., Davey, M., Ngallaba, S.E. and Konje, E. (2013). A cross-sectional survey on knowledge and perceptions of health risks associated with arsenic and mercury contamination from artisanal gold mining in Tanzania. BMC Public Health.13(74), 1-8.

[8] Basu, N., Clarke, E., Green, A., Calys-Tagoe, B., Chan, L. Dzodzomenyo, M., Fobil, J., Long, R.N., Neitzel, R.L., Obiri, S., Odei, E., Ovadje, L., Quansah, R., Rajaee, M. and Wilson, M.L. (2015). Integrated assessment of artisanal and small-scale gold mining in GhanaPart 1: Human Health Review. Int.J.Environ.Res. Public Health.12,5143-5176.

[9] Yard, E.E., Horton, J., Schier, J.G., Caldwell, K., Sanchez, C., Lewis, L. and Gastanaga, C. (2012). Mercury exposure among artisanal gold miners in Madre de Dios, Peru: A cross-sectional study. J.Med.Toxicol. 8,441-448.

[10] Male, Y.T., Reichelt-Brushett, A.J., Pocock, M. and Nanlohy, A. (2013). Recent mercury contamination from artisanal gold mining on Buru Island, Indonesia-Potential future risks to environmental health and food safety. Marine Pollution Bulletin. 77(1-2),428-433.

[11] Lestarisa,T. (2010). Faktor-faktor yang berhubungan dengan keracunan merkuri $(\mathrm{Hg})$ pada penambang emas tanpa izin (PETI) di Kecamatan Kurun, Kabupaten Gunung Mas, Kalimantan Tengah. Tesis. Semarang:Universitas Diponegoro.

[12] Subanri. (2008). Kajian beban pencemaran merkuri $(\mathrm{Hg})$ terhadap air sungai Menyuke dan gangguan kesehatan pada penambang sebagai akibat penambangan emas tanpa izin (PETI) di Kecamatan Menyuke Kabupaten Landak Kalimantan Barat. Thesis. Semarang: Universitas Diponegoro.

[13] Castilhos,Z.C., Rodrigues-Filho,S., Rodrigues, A.P.C., Villas-Boas, R.C., Siegel,S., Veiga, M. and Beinhoff, C. (2006). Mercury contamination in fish from gold mining areas in Indonesia and human health risk assessment. Science of the Total Environment. 368,320-325.

[14] Sofia, Husodo,A.H. and E. Sugiharto. (2016). Acute and chronic toxicity of mercury exposure in seafood and human populations near a smallscale gold mining area. International Journal of Public Health Science, 5(3), 257-266.

[15] WHO (World Health Organization). Mercury: Assessing the burden of disease at national and local levels. Environmental burden of disease series, No.16. Geneva: WHO [Online]. Available: http://whqlibdoc.who.int/publications/2008/9789241596572 eng.pdf

[16] Bull. HPS Compendium of chemical hazard. In Health Protection Agency.(2011). United Kingdom.

[17] Farina, M., Rocha, B.T.J. and Aschner, M. (2011). Mechanisms of methylmercury-induced neurotoxicity: Evidence from experimental studies. Journal of Life Sciences. 89, 557-559.

[18] Rafati-Rahimzadeh, M., Rafati-Rahimzadeh, M., Kazemi, S. and Moghadamnia, A.A. (2014). Current approaches of the management of mercury poisoning:need of the hour. DARU Jounal of Pharmaceutical Sciences. 22(46), 1-10.

[19] Brodkin, E. , Copes, R., Mattman, A., Kennedy, J., Kling, R and Yassi, A. (2007). Lead and mercury exposures: interpretation and action. CMAJ. 176(1),59-63.

[20] Rianto, S. (2012). Analisis faktor-faktor yang berhubungan dengan keracunan merkuri pada penambang emas tradisional di desa Jendi Kecamatan Selogiri Kabupaten Wonogiri. Jurnal Kesehatan Lingkungan. 11,58-59.

[21] Silbergeld, K.E., Silva, I.A., Nyland, J.F. (2005). Mercury and autoimmunity: implications for occupational and environmental health. Toxicology and Applied Pharmacology. 207,283-284.

[22] Wardiyatun, S. and Hartini. (2009). Faktor-faktor yang berhubungan dengan kadar merkuri dalam urine pada pekerja tambang emas di desa Rengas Tujuh Kecamatan Tumbang Titi Kabupaten Ketapang Kalimantan Barat. Jurnal Visikes. 5,139-140. 